\title{
The Portrayal of Occultism in "The Call of Cthulhu" (1928) by H.P. Lovecraft
}

\author{
Evan Arnoldi Sebayang ${ }^{1}$; Bayu Kristianto ${ }^{2}$ \\ Universitas Indonesia, INDONESIA \\ e-mail: evanarnoldisebayang@gmail.com¹; baladewabayu@gmail.com²
}

\begin{abstract}
H.P. Lovecraft crafted an intricate mythos which initially did not find success until after his death, and his works, most notably "The Call of Cthulhu" (1928), were regarded to be a landmark on the relevance of occultism both in the field of literature and religious belief. The short story was regarded to be the staple of "cosmic horror" which Lovecraft applied to almost all of his stories. This paper analyzes how "The Call of Cthulhu" influenced the belief of modern occultism, which can be inferred from the literary elements in the story. Further analysis identifies how Lovecraft portrayed the subgenre "cosmic horror" to enhance the elements of occultism within the short story. In relation to the previous elements, the paper examines how a particular cult, Typhonian Order, was influenced by the elements of occultism used in the story. The research concludes that the short story portrays elements of occultism such as rituals and cultists exaggeratedly malicious and twisted, uses literary elements such as "fear of the unknown" and "ancient ambience" to enhance Lovecraft's depiction of occultism in the short story, and influences the Typhonian Order as the cult's leader, Kenneth Grant, adopts several elements of the short story to the order's teachings.
\end{abstract}

Keywords: Cthulhu mythos; occultism; the call of Cthulhu; h.p. lovecraft; typhonian order.

\section{INTRODUCTION}

"Meanwhile the cult, by appropriate rites, must keep alive the memory of those ancient ways and shadow forth the prophecy of their return" (Lovecraft, 1928, p. 170).

An otherworldly monster slumbering deep behind a giant monolithic dimensional gate, waiting to be awoken before consuming the entire world, and the only person who knew of its existence had been permanently silenced by a cult, dedicated to the being known as "Cthulhu" and its revival from the eternal slumber. At first glance, the summary of the short story sounds very unrealistic to happen in the real world. However, the scenario came into reality when certain words are swapped into the ones related to the first half of 2020, such as "an otherworldly monster slumbering deep behind a giant monolithic dimensional gate, waiting to be awoken before consuming the entire world" changed into "dormant fatal virus inhabiting exotic animals." Perhaps Lovecraft himself had foreseen that such apocalyptical events would happen in the future and wrote his version of it back in 1928, when "The Call of Cthulhu" was first published. The short story also strongly influenced horror literature and a specific belief system of occultism, which is the Typhonian Order's belief system, decades following his death.
The short story is about an investigative manuscript of the late Francis Wayland Thurston, who had passed away when the journal was discovered. The manuscript opens with how the writer feels that some things are better left unknown and that the horror he encounters is not worth the knowledge he gathers. $\mathrm{He}$ recounts how he first discovered the activities of the certain Cthulhu Cult after inheriting the belongings of his late grand-uncle, George Gammell Angell, a professor with expertise in ancient inscriptions. The story climaxes when he read the diary of Gustav Johansen, the captain of the Emma ship, who personally encountered Cthulhu in the form of a horrific creature with a "tentacled" (Lovecraft, 1928, p. 161) head and rudimentary wings, located behind a great granite monolith which served as a dimensional portal to the place of Cthulhu. In the end, Thurston hopes that if he dies due to the same mysterious circumstance as Angell and Johansen, inferred to be at the hands of the cultists, the manuscript that he had written will be sealed away from others' eyes to ensure they do not meet the same fate as himself.

His works had also created his own subgenre of horror called "cosmic horror," which also has been called "Lovecraftian horror" by some researchers and authors (Emrys, 2018). The subgenre is regarded to be one of the most influential in terms of horror literature by contemporary writers (Wohleber, 1995), became a 
huge hit, and gained a significant following throughout the world. Unfortunately, this happened in the distant future, more than eighty years after Lovecraft passed away, as his works only gained few followers during his life. The subgenre of cosmic horror itself has been regarded to be moving out from the norm of horrors at that time, as it was dominated by demons, ghosts, and vampires, unrealistic mythical beings compared to the Darwinian evolution theory-inspired monsters by Lovecraft (Wohleber, 1995). It is safe to say that Lovecraft invented a new way of storytelling in horror literature.

A number of research has been done to identify Lovecraft's influence and ideas within his literature. Zeller (2019) in "Altar Call of Cthulhu: Religion and Millenialism" argues that Lovecraft conveyed his idea of "anti-millennialism" which views humanity's future as bleak and heading towards "ultimately meaningless end" (p. 6) in his literature, including "The Call of Cthulhu" (1928). The paper mentions his other works such as "The Dunwich Horror" (1928) with no particular focused analysis for the elements of the occultism influenced by the short stories. Pérez de Luque (2013) analyzed the short story and several other of Lovecraft's works in the dissertation titled "Communal decay, narratological and ideological analysis of H.P. Lovecraft's fiction." He came into the conclusion of how Lovecraft's ideological background influenced his literature and developed "an interesting philosophical, metaphysical, cultural, and ideological background" (Pérez de Luque, 2013, p. 351), with no mention regarding the pervasive elements of occultism existing throughout the short story. Snyder's (2017) analysis on the short story regarding the usage of "fear of the unknown" is also elaborated in this paper as one of the pervasive elements used in the story, with the difference that this paper focuses on how the element itself portrays occultism in the time period of the short story's creation, as Snyder's paper only briefly touched upon the presence of occultism in the element. He explores the idea of occultism succinctly by analyzing Lovecraft's attempt at creating "occult lore" for his short stories to enhance traits of his characters in his stories (Snyder, 2017, p. 5 \& 12).

In addition, there are other articles which elaborate on how Lovecraft influenced occultism through his works. As stated by Engle (2014), despite Lovecraft's status of not being an occultist himself, his works are considered as ample resources to deepen one's knowledge about occultism. Bolton (2011) elaborated further that the Lovecraftian Mythos itself can be used as a reference point for a whole new system of occultism theory, as it contains elaborate systems of rituals which can be realistic enough to be practiced in real life. However, both articles included his other works including The Shadow Over Innsmouth (1936), and also other cults including the Esoteric Order of Dagon and the Lovecraftian Coven, the latter of which will be referenced in this analysis as one of the examples of the cults influenced by the short story. Engle's (2014) findings on several aspects of the Typhonian Order's rituals such as orgies and practices "in the name of the Lovecraftian deities" (Engle, 2014, p. 91) that are not specified to have been adapted from one of Lovecraft's pieces of literature will be expanded further in this paper, and Bolton's general analysis on cults influenced by Lovecraft's numerous literature which lacked focus on a particular literature will also be complemented further by the focused analysis of this paper on the short story "The Call of Cthulhu" and its influence on the Typhonian Order's belief system. The focus of this paper will only be on "The Call of Cthulhu" (1928) and the Typhonian Order, unlike the previously mentioned papers, which grapple with a number of Lovecraft's works. The focus will enable deeper analysis on literary elements in the short story, which previous research may only mention as additional elements instead of the main point of the analysis. The short story's specific literary elements such as the existence of Cthulhu, the rituals involving Cthulhu's aspect such as tentacles, were adapted by Typhonian Order's belief system. With that in consideration, the short story "The Call of Cthulhu" and the Typhonian Order became the focus of this research.

Therefore, this paper will first analyze elements of occultism present in the story and how Lovecraft twisted the representation of occultism due to his views on it. Second, literary elements present in the short story, such as "fear of the unknown" and "ancient ambience," will also be analyzed to observe Lovecraft's attempt to enhance elements of occultism present in the short story. Finally, the paper will also analyze the short story's impacts on occultist practices by taking a closer look at one of the cults that adapted modern occultism into its teachings, the Typhonian Order, and the short story's influence on the belief system adopted by the cult.

\section{Occultism}

As the core of the paper's analysis, it is imperative to identify what occultism is, a brief explanation of its history and its modern version. Occultism has been a way of life for certain groups of people since ancient times, taking the form of various activities such as tarot readings, numerology, clairvoyance, séance, and astrology, which are still prevalent in recent times. The earliest published writings in English containing the word "occultism" dated back to 1875 , when Helena 
Blavatsky introduced the concept by publishing an article in the American Spiritualist magazine, Spiritual Scientist. In the article, titled "A Few Questions to "Hiraf"' (1875), Helena elaborated on how occultism could be very dangerous if the disciples of the mentioned way of life did not dedicate their time to pursuing and educating themselves about it, as it could lead to a dangerous way of thinking, and they would become radicalized. Occultism itself has been used in various works of literature throughout history as an attempt to rationalize metaphysical occurrences in a myriad of literature, defining the magical moments as a logical event to happen instead of leaving them as a fantastical occurrence. Modern occultism is defined by its adoption of belief systems from not only Western civilizations but also Eastern civilizations, such as Egypt and Japan (Galbreath, 1971, p. 736). As such, it can be inferred that, unlike traditional occultism, modern occultism derives its values from various other belief systems and is open to multiple interpretations, which explains the ensuing influence of the short story, "The Call of Cthulhu," on Typhonian Order's modern occultism.

\section{Cosmic Horror}

Lovecraft's short stories are influential enough in horror fiction to create a new subgenre called "cosmic horror," which involves allusions to deities incomprehensible to humanity and hopelessness against them throughout the story. Lovecraft first used the subgenre in one of his earliest works called "Dagon" (1917), in which he used several writing techniques in order to create the ambience of "cosmic horror" in the story. Conceptually, this subgenre involves the usage of cosmic deities which cannot be comprehended by a human, and any attempt to do so would result in madness. There is also a prevalent oppressive atmosphere which the readers can feel by reading about the bizarre happenings around the protagonist of each story, especially in "The Call of Cthulhu." Cosmic horror can be identified by its characteristics of making the reader feel lost as many things are left ambiguous enough to keep them guessing, but with clues of what the truth is to keep them engaged with the story. Ralickas (2008) also mentioned the sense of dread which kept the readers feeling "fear and awe" before the cosmic being whose scope "extends beyond the narrow field of human affairs and boasts of cosmic significance." The other attribute of the subgenre is the prevalence of the law of physics being twisted by the existence of the cosmic beings, as they play by their own rules instead of following the law of causality. The protagonist of the short story, Thurston, sums up the subgenre of cosmic horror in the second half of the story: "Was I tottering on the brink of cosmic horrors beyond man's power to bear?" (Lovecraft, 1928, p. 174).

\section{Imagery and Foreshadowing}

Combining both occultism and cosmic horror in the story, Lovecraft extensively uses imagery (Blacklock, 2017) and foreshadowing (Anderson, 1992) throughout the short story. According to Riffaterre (1981), imagery is the usage of literary description which includes but is not limited to "visual, auditive, olfactory sensations" (p. 116) to convey an interpretation of reality according to the writer's will. Foreshadowing is a literary technique used to give hints about certain events which happen in a particular way as a "consequence of events to come" (Morson, 1996, p. 7). Both literary elements augment the mysterious nature of occultism and the dreaded atmosphere of cosmic horror. Their prevalence in "The Call of Cthulhu" make them essential to be analyzed further in the latter part of the paper.

\section{ANALYSIS}

\section{OCCULTISM IN "THE CALL OF CTHULHU"}

Elements of occultism can be identified in several parts of the short story, most notably the existence of the Cthulhu Cult and the rituals done by the cultists, who are portrayed to be hideous in appearance. The characteristics and values of the Cthulhu Cult themselves can be implied to be based on occultism, with its characteristics and tenets which its members uphold strongly resembling the practices and rituals of occultism. However, the resemblance does not entirely represent the actual values of occultism in the short story, as both the rituals and appearance of the cultists are portrayed to be dangerous and hideous despite the real life practices of occultism. This section will discuss the actual values and exaggeration of both the rituals and the cultists in the short story.

\section{Rituals}

Rituals are fundamental in occultism, and Lovecraft portrayed them to be quite sinister with the usage of human sacrifices, in contrast to the otherwise elaborate but perfectly safe and legal rituals. Occultism does require absolute dedication from its believers or occultists by having them perform certain rituals to affirm their faith. However, the rituals themselves do not involve human sacrifice and practices which may harm other living beings in the process. The rituals in occultism are quite elaborate, involving certain elements and items such as a magic circle and altar, which are sometimes necessary (Lloyd, 1978, p. 66). The rituals mainly have the purpose of keeping one's faith in the occultism intact, rather than to appease a particular malevolent entity which Lovecraft had alluded to in the short story, as elaborated by Conway (2016). 
An explanation of such rituals is given by Conway (2016) as a guideline for the occultists or believers of a belief to concentrate on their faith, exploring their link with the object of their own belief, be it in the form of a higher being as a traditional Abrahamic religion usually explores, or an esoteric diagram which is believed to be the source of life itself such as the "Tree of life" in the Kabbalistic rites. As such, Lovecraft's writing of the Cthulhu Cult itself was an exaggeration of the occultism practices, as the cult practices the same fundamental values of occultism, which involves rituals and a strict way of life in their tenets. It also confirms how Lovecraft tried to adopt several elements and values of occultism into his story. One example of the depiction of the rituals can be seen in this quote from the short story: "These words had formed part of that dread ritual which told of dead Cthulhu's dreamvigil in his stone vault at R'lyeh, and I felt deeply moved despite my rational beliefs" (Lovecraft, 1928, p. 172). The quote itself described how the rituals are conducted by the worshippers appearing in Henry Anthony Wilcox's dream, a sculptor who unknowingly made a figurine of Cthulhu despite his obliviousness of Cthulhu and its cult, to be disturbing enough that Thurston felt "moved" by the words recited in the ritual, which is "Cthulhu fhtagn." (Lovecraft, 1928, p. 172)

It can be alluded that Lovecraft attempted to portray the values of ancient rituals often conducted by practitioners of occultism in the form of the ritual done by the Cthulhu Cult in the fictional language of "R'lyehian," made by the cultists who were trying to decipher the otherworldly non-human noise made by Cthulhu, which sounds like "chorus of hoarse voices" chanting "that hideous phrase or ritual." The translated version of the quote itself, according to one of the cult members, is "In his house at R'lyeh dead Cthulhu waits dreaming" (Lovecraft, 1928, p. 166). From this passage, it can be concluded that Lovecraft had attempted to dismiss the ancient "ceremonial magic" or prayers usually performed by occultists as insignificant, or yet, much more malicious by branding those chants or rituals as an attempt to contact an inexplicable evil that might exist in the vast unknown space.

Another depiction of the exaggeration can be seen in a passage in the story, when Thurston detailed the process of interrogation of the cultists who performed a sacrificial ritual involving humans, while they claimed innocence to the crime either due to their paranoia or the actual account of what happened during the ritual: "All denied a part in the ritual murders, and averred that the killing had been done by Black Winged Ones which had come to them from their immemorial meeting-place in the haunted wood"
(Lovecraft, 1928, p. 167). It can be assumed that the particular "ritual murder" is the act of human sacrifice which the cult has conducted in their rituals for an unknown period of time. This particular passage can be understood to be Lovecraft's attempt to either depict cultists as dangerous schizophrenic members of the society which may bring harm to themselves and others or portray the inherent danger of conducting such a ritual which may summon a particular creature with harmful intentions towards humans. The general perception regarding occultists at the time of the short story's creation can be regarded to be ambivalent enough that the public tended to tolerate their activities which included rituals and attempts at pseudoscience in scholarly research, as seen in the high numbers of the cult members participating in the 1930 Census, with their own occupations being listed such as "physicians, dentists, nurses, osteopaths, and chiropractors" (Stark et al., 1981, p. 157). The perception can be identified to be a source of inspiration for Lovecraft to "uncover" another side of them he considered to be abhorrent, which is the cult's secretive nature and also their belief of occultism which, ironically, he influenced after his time of death.

Thus, the depiction of the bizarre rituals in the short story can be concluded to be Lovecraft's attempt to both include elements of occultism in his story in an exaggerated fashion. He created the narrative of the cultists to be worshipping a malevolent being demanding the sacrifice of human beings, and with the destructive intention upon the world itself, which will be expanded further in the next section.

\section{The Cultists of Cthulhu}

Lovecraft's portrayal of the cultists in the short story also serves as further evidence on how he exaggerated elements of occultism in the short story, particularly the practitioners of the belief themselves, as they were considered to be well-respected, and "tolerable" at worst, by the public at that time. Such portrayals can be seen in the following excerpt of the story: "Then the liberated Old Ones would teach them new ways to shout and kill and revel and enjoy themselves, and all the earth would flame with a holocaust of ecstasy and freedom" (Lovecraft, 1928, p. 170). This can be deduced to be Lovecraft's attempt at writing about the existing cultists in the story as homicidal, willing to raise their sealed "Old Ones" in order to have the freedom to slaughter their fellow humans to experience the "holocaust of ecstasy and freedom." The cultists are depicted further as "backwoods or inbred degenerates, barely human any longer" (Engle, 2014, p. 94). The occultists at the time of the short story's creation, quite the contrary, were quite respected and active in the 
society, most of whom worked in the public sector such as "counseling, social work, teaching, and health care," as elaborated by Jorgensen \& Jorgensen (1982, p. 377). The reason behind this exaggeration of the cultists' depiction can be assumed to be caused by certain cases which involved a particular cult at that time, which will be elaborated in the further part of the analysis entitled "The Typhonian Order," and also the author's unsympathetic stance towards cults and their followers.

The cultists are also depicted to be secretive due to their harmful intention to resurrect Cthulhu, which would inflict chaos upon the world, and also the nature of their rituals which involve human sacrifice. Thurston expanded further on this secretive element of the cult in the short story in this particular passage: "For I felt sure that I was on the track of a very real, very secret, and very ancient religion whose discovery would make me an anthropologist of note" (Lovecraft, 1928, p. 172). This can be conjectured to be another Lovecraft's allusion towards real life cults in his time, which were secretive and required elaborate oaths of secrecy from its members, one example being the Hermetic Order of Golden Dawn, with the difference being the fatal tendencies of Cthulhu Cultists and the generally normal activities done by the cultists of the Golden Dawn. Winslade (2000) elaborated the secretive nature further in this particular quote: "Initiation introduces the novice to the secret knowledge, often by physically bringing the initiate into the space where the secret is hidden: the temple, the cave, the concealed alcove, the crypt, the library" (Lovecraft, 1928, p. 90).

Contrary to the portrayals in the short story, the occultists at that time tended to be well-adjusted, economically secure, and most of the time were in a healthy state of mind. The short story portrays the cultists to be horrifying and abnormal enough that even hardened police officers cannot stand the sight of them, as seen in this particular excerpt of the story: "On this now leaped and twisted a more indescribable horde of human abnormality than any but a Sime or an Angarola could paint" (Lovecraft, 1928, p. 168). The quote contrasts with the general appearance of occultists at that time. For example, many adherents of such belief in the beginning of the $19^{\text {th }}$ century belonged to the middle and upper-class Anglican church members, including the clergy themselves (Stark et al., 1981, p. 144). Even the practice of occultism itself is said to be open to anyone that wanted to adhere to the belief, a view shared by Jorgensen \& Jorgensen (1982), who elaborated that "almost anyone may begin an occult practice" (Lovecraft, 1928, p. 378), although it required further commitment should one wish to be considered as an occultist. This can be taken as another example of how Lovecraft used several elements of occultism in his story and twisted them to conform to the theme of his story, which resulted in the perceived negative portrayal of the elements of occultism in the short story.

\section{LITERARY ELEMENTS PORTRAYING OCCULTISM}

Lovecraft used literary elements such as "fear of the unknown" and "ancient ambience" to convey his take on occultism in the story, enhancing the horror theme present in the story. The elements of occultism are also present in the subgenre of the story, which can be called "cosmic horror" due to the usage of cosmic elements and various other literary elements present in the story, including foreshadowing and imagery.

\section{Fear of the unknown}

In the short story, Cthulhu Cult is secretive and hidden from civilization as they perform rituals deep in a country of swamps and lagoons. Although the cult are hidden, Francis, the main character, regards them to be deadly enough that they murdered his professor and that he feels he is on borrowed time, although he never saw them personally. Francis' paranoia can be regarded as one example of fear of the unknown in the story, with a background related to occultist practices.

The mysterious aspect of the Cthulhu Cult in the story is suggested to be an allusion towards secretive cults formed under the belief of occultism, such as the Hermetic Order of the Golden Dawn, although the allusion might be made accidentally, as elaborated by Levenda (2013, p. 109). The order itself ordered their members to "accept aliases and to define motoes" in order to disassociate their cult identity with their public identity (Meyer, 2010, p. 13). It is a human's instinct to be fearful of the unknown, as it could potentially be hazardous to one's life, a trait that can be traced to the ancestor's way of life, which included hunting dangerous wildlife in order to survive. Riezler (1944, p. 493) elaborated that even a courageous soldier would fear an unknown situation which he or she might face on a battlefield. Lovecraft took advantage of this natural reaction further by placing the characters in his stories to be facing an insurmountable danger which cannot be comprehended, as even knowledge would appear to be dangerous and could lead to madness. He further stated that: "and there must be a hint, expressed with a seriousness and portentousness becoming its subject, of that most terrible conception of the human brain" (Lovecraft, 1927).

Imagery of the "fear of the unknown", portrayed by occultism in the story, can also be inferred to be ever- 
present in this particular literary subgenre due to Lovecraft's tendency to include elements of occultism in the subgenre (Evans, 2005, p. 123). One example of such existential fear of the Cthulhu Cult felt by Thurston can be seen in this particular excerpt from the story:

One thing I began to suspect, and which I now fear I know, is that my uncle's death was far from natural. He fell on a narrow hill street leading up from an ancient waterfront swarming with foreign mongrels, after a careless push from a Negro sailor. I did not forget the mixed blood and marine pursuits of the cult-members in Louisiana, and would not be surprised to learn of secret methods and rites and beliefs. (Lovecraft, 1928, p. 172)

It can be seen that Lovecraft used his own brand of subgenre to integrate his own take of occultism in the story to create a mix of horror and dread which can be deemed to be "real" and unsettling enough to mirror the events in real life. One particular event can be seen from an excerpt of the short story as Thurston tries to piece together the events which happened in the short story: "And most marvellous of all, what deep and more than natural linkage of dates was this which gave a malign and now undeniable significance to the various turns of events so carefully noted by my uncle?" (Lovecraft, 1928, p. 174). He further developed this way of storytelling by adding archaic vocabulary to his stories, such as "large congeries of iridescent" and "prolately spheroidal bubbles" (Blacklock, 2017, pp. 1111-1112) in order to let the reader's imagination run wild on what could be an interesting technique of imagery. As such, it is possible that Lovecraft tried to incorporate values of occultism into the subgenre in order to immerse the reader further into the story while also experimentally devising another side of occultism involving the Cthulhu Cult and its destructive nature that could inflict unrest to the society.

Lovecraft used foreshadowing extensively throughout the short story to make the readers feel further dread on what would bound to happen in the course of the story. Aside from the mentioned death of the main character on the first page of the short story, this particular passage recalling an earthquake happening before Wilcox, a sculptor, begins creating Cthulhu's hideous stone statuette can be considered as a foreshadowing: "There had been a slight earthquake tremor the night before, the most considerable felt in New England for some years; and Wilcox's imagination had been keenly affected"' (Lovecraft, 1928, p. 162). A passage mentioning earthquake can be found again in the latter part of the story, which affected poets and artists as they dreamt of "a strange, dank Cyclopean city" (Lovecraft, 1928, p. 174). It can be inferred that these earthquakes were signs of Cthulhu giving visions and becoming free of its seal bit by bit, up until unwitting heroism is done by a group of sailors to push the deity back to its confinement (Lovecraft, 1928, p. 173-178).

Another example is Thurston's constant fear of Cthulhu and the impact it will inflict upon the world if it is successfully resurrected by the cultists, as seen in this short passage from the short story:

He must have been trapped by the sinking whilst within his black abyss, or else the world would by now be screaming with fright and frenzy. Who knows the end? What has risen may sink, and what has sunk may rise. Loathsomeness waits and dreams in the deep, and decay spreads over the tottering cities of men. A time will come - but I must not and can not think! (Lovecraft, 1928, p. 287)

It can be surmised from that particular passage that Thurston himself was living in constant fear of the apocalypse itself, and at the same time, his own death by the hands of the cult, a conclusion he might expect from himself after knowing his uncle's particular suspicious death, hinted to be at the hands of the cultists. The irony can be seen as his prediction became real, as the manuscript itself was found to be "found among the papers of the late Francis Wayland Thurston" (Lovecraft, 1928, p. 159). Lovecraft managed to use this particular literary element to strengthen the theme of occultism present in the short story and the oppressive atmosphere in the story, which makes the reader expect that disasters are bound to happen sooner or later in the short story.

\section{Ancient ambience}

Frequent usage of archaic language and description of ancient structures in the short story can also be inferred to be intended by Lovecraft in order to both enhance the reader's imagination in perceiving the incomprehensible nature of his own cosmology and the mythical atmosphere of the story itself. One of the examples would be the prevalent usage of architecture in the short story, which includes monoliths and colossal statues: "Awe at the unbelievable size of the greenish stone blocks, at the dizzying height of the great cavern monolith, and the stupefying identity of the colossal statues and bas-reliefs" (Lovecraft, 1928, p. 160). The imagery of ancient structure further enhances the unsettling and mystical atmosphere of the short story, which can be inferred to be one of the main influences Lovecraft has upon modern occultism. Practitioners of modern occultism encourage the usage 
of ancient objects and remote locations to channel the "energy of nature" within their rituals, similar to what Lovecraft alluded to in the short story.

The inclusion of art objects such as "very ancient stone statuette" and "great carven monolith" (Lovecraft, 1928 , p. 165 \& 176) can also be related to the fact that occultism regards art as one of the conduits for mystical events to happen. The art objects are believed to be capable of harnessing mystical energies in certain places of rituals but regarded to be optional due to the perceived limited availability throughout the world, a sentiment shared by Conway (2016) when he explained the process of rituals. One example of this happening in the short story can be seen in this passage:

The statuette, idol, fetish, or whatever it was, had been captured some months before in the wooded swamps south of New Orleans during a raid on a supposed voodoo meeting; and so singular and hideous were the rites connected with it, that the police could not but realise that they had stumbled on a dark cult totally unknown to them, and infinitely more diabolic than even the blackest of the African voodoo circles (Lovecraft, 1928, p. 165).

The quote, taken from the perspective of Inspector Legrasse who is personally taking charge of the investigation of the cult, talks about how there are certain items that exist on the site of the rituals conducted by the Cthulhu Cult in the form of an idol, which also envisages Cthulhu's form and is inferred to be another sign that the cult might be something the authorities have not dealt with before.

It can be summarized that Lovecraft integrated his own take of occultism into the story by including them in various integral parts of the stories. His own preferred way of horror storytelling in the form of the subgenre "cosmic horror" also strengthened the presence of occultism in his story and was regarded to be a unique way of storytelling by various other contemporary horror authors such as Stephen King and Joyce Carol Oates (Mullis, 2015, p. 514). His own take of occultism in the story was regarded to be significant enough to influence the belief itself in the distant future after his death, which will be expanded further in the next section.

\section{PRACTICES OF OCCULTISM}

Occultism itself is derived from a belief existing in real life, with many practitioners adapting its values into their own beliefs and teachings, such as the Typhonian Order. However, the sheer intensity of Lovecraft's works had also influenced the belief of occultism, although the belief can be regarded as its own branch of occultism which is called "modern occultism." In this section, the Typhonian Order and modern occultism will serve as a link which bridges Lovecraft's influence on the real world in the form of a "cult" and "belief system."

\section{Cults and the Typhonian Order}

Occultism has given rise to several cults which gained both notoriety and fame due to their "occult" nature which may require rituals and absolute dedication from their followers. In the time period when Lovecraft published the short story, one of the cults which was infamous for its exploitations of its members was The Blackburn Cult, or also known as "Divine Order of the Royal Arms of the Great Eleven," which required tributes from each of its members while handing them empty promises of salvation and riches. The cult's demise culminated in the arrest of its leader, May Otis Blackburn, for swindling the money of her own followers ("California Cults," 1930, p. 3). Lovecraft perhaps drew some inspiration from the doomed cult due to the similarity between the cult's year of activities between 1922 and 1930, and the time the short story was published, which is 1928. The particular time period was made to be a reference point for cults to be abhorrent and their cultists to be hideous, as the resulting backlash of the cult's discovery by the authorities at that time was huge enough to spark a "Great AntiCult Scare" from 1935 until 1945 (Jenkins, 1999). An allusion towards this investigation of malicious cults in real life can be seen in the short story when the police are trying to investigate the Cthulhu Cult:

The statuette, idol, fetish, or whatever it was, had been captured some months before in the wooded swamps south of New Orleans during a raid on a supposed voodoo meeting; and so singular and hideous were the rites connected with it, that the police could not but realise that they had stumbled on a dark cult totally unknown to them, and infinitely more diabolic than even the blackest of the African voodoo circles. Of its origin, apart from the erratic and unbelievable tales extorted from the captured members, absolutely nothing was to be discovered; hence the anxiety of the police for any antiquarian lore which might help them to place the frightful symbol, and through it track down the cult to its fountain-head (Lovecraft, 1928, p. 165).

The description of the investigation of the Cthulhu Cult can be alleged to be parallel with the real life events surrounding The Blackburn Cult, which were suspected for strange rituals involving orgies, animal sacrifices, and even an attempt to resurrect a 16-yearold girl named Willa Rhoads (Young, 2002). 
The real-life example of a cult being influenced by Lovecraft's pieces of literature is the Typhonian Order (Bolton, 2011), which directly incorporated elements from Lovecraft's literature into its own teaching, as elaborated by the leader of the order himself, Kenneth Grant, about the authentic influence of Lovecraft's stories in the teachings of his order:

As entities, these forces have - in comparatively recent times - renewed their aeons-old interest in mundane affairs. They 'chose' Helena Blavatsky, Macgregor Mathers, Aleister Crowley, H.P. Lovecraft, and others, to reactivate and to unseal for Their requirements certain terrestrial powerzones. (Grant, 1999, p. 151)

Before the in-depth analysis is conducted on the influence of the short story in this particular order's teaching, it is imperative to know the background of the order before its newest inception under the leadership of Kenneth Grant. The Typhonian Order, formerly known as the Typhonian Ordo Templi Orientis (TOTO), was formed after a long-lasting struggle of power between the successors of Aleister Crowley, the original Outer Head of the Order and influential occultist in the $19^{\text {th }}$ century (Bogdan, 2015, p. 323). The struggle involves one of Crowley's successors, Karl Germer, proclaiming himself to be the true successor of Crowley's leadership, which was vehemently denied by Grant himself, who claimed to have received Crowley's blessing to continue his duty as the leader of the order and managed the order from another location. According to Bogdan (2015), this became pivotal in Grant's attempt to formulate his own "idiosyncratic understanding of Thelema and the OTO," (p. 327), which can also be suggested to be the beginning of Lovecraft's influence to the belief of the order. Thelema itself will be expanded further in the next part of the analysis.

Grant subsequently became the leader of the order after the struggle ended and incorporated his own brand of modern occultism, which was influenced by Lovecraft's literature, including the short story "The Call of Cthulhu" (1928). He believes Lovecraft was unaware of being the "conduit" of the deities which exist on a higher dimension and relayed visions in the form of dreams which resulted in the works of literature written by the author, as elaborated in this quote: "Understandably terrified of crossing the Abyss, he [referring to Lovecraft] forever recoiled on the brink, and spent his life in a vain attempt to deny the potent Entities that moved him. Little wonder the tales he wrote are among the most hideous and powerful ever penned"' (Grant, 1972). Grant further elaborated the importance of communicating with "Great Old Ones," ancient beings which await re-entry to the world as they left them in the past (Bogdan, 2015, p. 326). The great being referenced in the short story, Cthulhu, can be surmised to be one of the ancient beings which were referenced by Grant, as the manner of the resurrection of the being itself was similar to the "re-entry" of the "Great Old Ones" mentioned by Grant:

When the stars were right, They could plunge from world to world through the sky; but when the stars were wrong, They could not live. But although They no longer lived, They would never really die. They all lay in stone houses in Their great city of R'lyeh, preserved by the spells of mighty Cthulhu for a glorious resurrection when the stars and the earth might once more be ready for Them. (Lovecraft, 1928, p. 170)

It can be summarized that the short story inadvertently influenced the fundamental teachings of the cult, specifically the Typhonian Order, due to its thoughtprovoking and elaborate storytelling and literary elements. Further analysis of Grant's own brand of modern occultism, which was influenced by the short story, will be elaborated in the next part of the analysis.

\section{Modern Occultism: Thelema}

In regards to the modern occultism adapted by Typhonian Order, it is crucial to know first the history behind the specific belief system, referred as Thelema, adopted by the cult. A change of the Typhonian Order's leadership also affected the beginning of Lovecraft's influence on the cult's belief system. Thelema was created in the early 1920s by Aleister Crowley, inspired by François Rabelais' novel Gargantua (1534), which criticized Christian monasteries' "hypocritical corruption" (Urban, 2004, p. 10). Crowley developed the idea of having a utopian community which allows the members to indulge in their desire by partaking in hedonistic activities, blending them with his own take of esoteric traditions of Tantra and European magical arts. (Urban, 2004, p. $10 \& 12$ ). Grant later invented his own iteration of Thelema by using Lovecraft's system of magic and ritual found in the short story, such as Cthulhu Cult's secrecy among the society, and also the frequent orgies similar to the ones depicted in the short story: "The present voodoo orgy was, indeed, on the merest fringe of this abhorred area, but that location was bad enough; hence perhaps the very place of the worship had terrified the squatters more than the shocking sounds and incidents" (Lovecraft, 1928, p. 167). Engle (2014) elaborated further by saying: "Many strange and bizarre rites have been performed by the group over the years, including a kind of Lovecraftian sex magic that involved, according to Grant's description, a certain amount of what could only be called "tentacle play" 
(p. 92). "Tentacle play" itself is a term for an act of ritualistic sex involving the usage of fake tentacles, which can be deduced to simulate Cthulhu's appearance with its tentacular appendages, as seen in this excerpt from the short story describing its appearance: "A pulpy, tentacled head surmounted a grotesque and scaly body with rudimentary wings; but it was the general outline of the whole which made it most shockingly frightful" (Lovecraft, 1928, p. 161).

Further evidence of Lovecraft's influence can be seen from Kenneth Grant's attempt to incorporate elements from Lovecraft's works into modern occultism. Grant regarded The Necromonicon, a fictional grimoire made by Lovecraft that appears in the short story, to be based on reality instead of a fictional origin, and associated much of the book's content with his own belief of occultism, as seen in this particular excerpt from his book: "To Lovecraft they appeared as characters in a grimoire of forbidden lore entitled the Necronomicon, the contents of which teem with references to the Outer Ones. Their reflexes are the Deep Ones and the nameless elementals which haunt the pages of Lovecraft's tales"'(Grant, 1999, p. 15). The appearance of the grimoire can be seen in this short passage in the short story:

No book had ever really hinted of it, though the deathless Chinamen said that there were double meanings in the Necronomicon of the mad Arab Abdul Alhazred which the initiated might read as they chose, especially the much-discussed couplet: That is not dead which can eternal lie, and with strange aeons even death may die (Lovecraft, 1928, p. 170).

Grant elaborated in his own occult texts that Lovecraft had indirectly elevated the belief of occultism by merely writing about his "dream" through his short stories, inspired by a higher being manipulating Lovecraft's dreams (1999, p. 14). Engle (2014) noted that the rituals which Grant performed with his own cult could be described to be "strange and bizarre rites," derived from Lovecraft's depiction of the ritual in the short story (p. 91). Identifying Lovecraft's inspiration to be prophetic visions of a higher being seems far-fetched. However, it is one that Grant believed to be true and incorporated within his own belief and teachings, subsequently adapted by the order which he presided over until his death in 2011.

Another direct reference made by Grant (1999) to the short story can also be seen in his theory on the secret spell, or codewords, of opening "gates", which can be related to relics of past civilizations. He assumed the past civilization's appearance akin to aliens, identified to be similar to ancient Egyptian mythologies that can be assumed to be the key to unlocking one's potential to be enlightened on a cosmical scale (Grant, 1999). The reference can be seen in this particular quote: "Lovecraft has revealed a potent 41-lettered spell for opening the Silent Gate," (Grant, 1999, p. 25) with an added footnote which elaborates the spell to this particular chant: "Ph'nglui mglw'nafh Cthulhu R'lyeh wgah'nagl fhtagn." The same chant can be found in the short story within this particular quote: "Now and then the less organized ululations would cease, and from what seemed a well-drilled chorus of hoarse voices would rise in singsong chant that hideous phrase or ritual: "Ph'nglui mglw'nafh Cthulhu R'lyeh wgah'nagl fhtagn" (Lovecraft, 1928, p. 168). The usage of the fictional Cthulhu Cult's phrasal ritual chant in his teachings provides another proof how Lovecraft influenced Grant's systemic belief of modern occultism.

Grant's role in influencing occultism by using literary elements from Lovecraft's works serves as significant pieces of evidence on how Lovecraft influenced the later iteration of occultism through his works, most notably "The Call of Cthulhu" (1928). It can be concluded that although his works are not meant to be taken too literally, and it is pure fiction, some occultists were fascinated by the intricate mythos in the story that they came to a conclusion Lovecraft himself might not have been aware that he had been used as a vessel by a higher being to communicate with human beings and adapted those writings as if they were the "gospels" of occultism.

\section{CONCLUSION}

Lovecraft had created an intricate mythos of Cthulhu with numerous elements borrowed from the belief of occultism and managed to influence the belief itself due to its fascinating and sophisticated style of writing and beautifully crafted system of belief. The values of occultism he had adapted into the story consists of the elaborate rituals and the cultists themselves, although he twisted the depiction to be quite vindictive by the deformed appearance of the cultists in the short story and their innate destructive objective in reviving Cthulhu, which may inflict apocalypse upon the world. The elements of occultism were also adapted into the subgenre of his own invention, which is called "cosmic horror," into a significant effect which immerses the readers into the short story with the elaborate setting that involves the elements of "fear of the unknown" and "ancient ambience." The elements resulted in the influence the short story had upon the belief of occultism itself, which can be called "modern occultism," to differentiate the modern belief from the old traditional belief. The short story also influenced real- 
life cult and religious belief, inspired by the elaborate plot and setting of the short story itself, namely the "Typhonian Order," which can be derived from the parallels those cults and beliefs had with some aspects of the short story.

The influence he had outside of the literary circle due to the short story's delayed success can also be attributed to his usage of elements of occultism throughout the so-called "manuscript," as readers at that time might not have been too keen on the idea of occultism yet as a part of fiction rather than real-life belief, as they had the belief as a part of their daily life due to the particular tumultuous period of time, which gave birth to many cults. Although some can be regarded to be quite harmful such as his indirect involvement in the birth of the several cults such as the Typhonian Order and Lovecraftian Coven, and also the ensuing influence it had over the "modern occultism," it can be assumed to be a reflection of how influential Lovecraft's works are, especially this particular short story, "The Call of Cthulhu." Lovecraft's admittance of receiving inspiration for the story from his dreams also serves as a foundation for the legitimacy in his stories by ardent believers of his role in expanding modern occultism as they believed his dreams were "visions" given by higher beings, one which can be paralleled with the particular quote in the story: "In his house at R'lyeh dead Cthulhu waits dreaming" (Lovecraft, 1928, p. 166).

However, there is still only few research dedicated to identifying the influence of "The Call of Cthulhu" on modern occultism itself, as some prefer to widen the scope of their research to include all of his works. For example, Engle's (2014) research on Lovecraft's influences on contemporary occult practices (2014) includes many of Lovecraft's literature instead of focusing on only one of them. The same applies to Bolton's inclusion of several other of Lovecraft's works and cults in his analysis of Lovecraft's influence towards occultism in general. This paper fills the research gap on how "The Call of Cthulhu" influenced aspects of modern occultism due to its elaborate story elements and twists of the traditional occultism values which, in turn, influenced the more "modern" occultism, specifically Kenneth Grant's Thelema.

Henceforth, it is hoped that this research could contribute to the process of identifying this particular short story's influence on the world of the occult, as the impacts can still be observed in recent times, with the resurging popularity of cults and alternative beliefs, and also inspire other writers to delve further into the untapped potential of the Cthulhu Mythos, particularly "The Call of Cthulhu." Lovecraft had influenced not only occultism but also created a whole new subgenre of horror, which many writers had adapted to their own writings, which is the cosmic horror. His influence in the literary horror scene is enormous, and there are also various other aspects of society that can be linked with his works, such as alternative beliefs and religious fervor, which were often depicted to be quite malicious in his works. Like the vast undiscovered universe itself, the Cthulhu Mythos serves as an unexplored frontier for everyone, waiting to be explored by every curious scholar.

\section{REFERENCES}

Anderson, J., A. (1992). Out of the shadows: A structuralist approach to understanding the fiction of $H$. P. Lovecraft. [Doctoral dissertation, University of Rhode Island]. Open Access Dissertations. https://digitalcommons.uri.edu/oa_diss/696/

Blacklock, M. (2017). Higher spatial form in weird fiction. Textual Practice, 31(6), 1101-1116. https://doi.org/10.1080/0950236X.2017.1358688

Bogdan, H. (2015). Kenneth Grant and the Typhonian tradition. In C. Partridge (Ed.), The occult world (pp. 323-330). New York: Routledge.

Bolton, K., R. (2011, February 10). The influence of H P Lovecraft on occultism. The Irish Journal of Gothic and Horror Studies, 9, 2-21. https://www. proquest.com/docview/1834037940

California Cults (1930, March 31). TIME, p. 3. http://content.time.com/time/subscriber/article/0, 33009,738983-2,00.html

Conway, D. (2016). Magic: An occult primer. Newport, RI: The Witches' Almanac.

Emrys, R. (2018, August 16). H.P. Lovecraft and the the shadow over horror. NPR. https://www.npr. org/2018/08/16/638635379/h-p-lovecraft-andthe-shadow-over-horror

Engle, J. (2014). Cults of Lovecraft: The impact of H.P. Lovecraft's fiction on contemporary occult practices. Mythlore: A Journal of J.R.R. Tolkien, C.S. Lewis, Charles Williams, and Mythopoeic Literature, 33(1), 85-98. https://dc.swosu.edu/ cgi/viewcontent.cgi?article $=1034 \&$ context=myt hlore

Evans, T. H. (2005). A last defense against the dark: Folklore, horror, and the uses of tradition in the works of H. P. Lovecraft. Journal of Folklore Research, 42(1), 99-135. http://www.jstor.org/ stable/3814792

Galbreath, R. (1971). The history of modern occultism: A bibliographical survey. The Journal of Popular Culture, 5(3), 726-754.

Grant, K. (1999). Beyond the mauve zone. London: Starfire Publishing Ltd.

Grant, K. (1972). The magical revival. London: Muller. 
Jenkins, P. (1999, June 2-4). The great anti-cult scare 1935-1945 [Conference presentation]. CESNUR's $13^{\text {th }}$ International Conference, Bryn Athyn, Pennsylvania, USA. https://www.cesnur.org/ testi/bryn/br_jenkins.htm

Jorgensen, D. L., \& Jorgensen, L (1982). Social meanings of the occult. The Sociological Quarterly, 23(3), 373-389. https://doi.org/10.1111/j.15338525.1982.tb01019.x

Levenda, P. (2013). The dark lord: H.P. Lovecraft, Kenneth Grant, and the Typhonian tradition in magic. Lake Worth, FL: Ibis Press

Lloyd, S. M. (1978). The occult revival: Witchcraft in the contemporary United States [Doctoral dissertation, University of Missouri Columbia] Proquest. https://www.proquest.com/openview/ 2eb35346d7315c69bb13134c72f8595b/1 ?pqorigsite $=$ gscholar $\& \mathrm{cbl}=18750 \&$ diss $=\mathrm{y}$

Lovecraft, H., P. (1928, February). The call of Cthulhu. Weird Tales, 11(2), 159-178 \& 287.

Lovecraft, H., P. (1927). Supernatural horror in literature. The recluse. Retrieved from www.hplovecraft.com/writings/texts/essays/shil.aspx

Meyer, T.-M (2010). Illuminating the occult: W. B. Yeats in Nick Bantock's Griffin and Sabine series. Journal of the Fantastic in the Arts, 21(1 (78), 5-25. http://www.jstor.org/stable/2435 2334

Morson, G., S. (1996). Narrative and freedom: The shadows of time. New Haven: Yale University Press.

Mullis, J. (2015). Playing games with the Great Old Ones: Ritual, play, and joking within the Cthulhu mythos fandom. Journal of the Fantastic in the Arts, $26(3$ (94)), 512-530. http://www.jstor.org/ stable/26321173

Pérez de Luque, J., L. (2013, 23 August). Communal decay, narratological and ideological analysis of H.P. Lovecraft's fiction [Doctoral dissertation, Universidad de Córdoba]. Helvia: Universidad de Córdoba Insitutional Repository. http://hdl.handle.net/10396/11479
Ralickas, V. (2008). Art, cosmic horror, and the fetishizing gaze in the fiction of H. P. Lovecraft. Journal of the Fantastic in the Arts, 19(3(74)), 297-316. http://www.jstor.org/stable/24352378

Riezler, K. (1944). The social psychology of fear. American Journal of Sociology, 49(6), 489-498. http://www.jstor.org/stable/2771546

Riffaterre, M. (1981). Descriptive imagery. Yale French Studies, 61, 107-125. https://doi.org/10. 2307/2929879

Snyder, P., J. (2017). Dreadful reality: Fear and madness in the fiction of $H$. P. Lovecraft (Honors thesis, University of Southern Mississippi). The Aquila Digital Community. https://aquila.usm. edu/cgi/viewcontent.cgi?article $=1546 \&$ context $=$ honors_theses

Stark, R., Bainbridge, W., \& Kent, L. (1981). Cult membership in the roaring twenties: Assessing local receptivity. Sociological Analysis, 42(2), 137-161. https://doi.org/10.2307/3710591

Urban, H. B. (2004). The beast with two backs: Aleister Crowley, sex magic and the exhaustion of modernity. Nova Religio: The Journal of Alternative and Emergent Religions, 7(3), 7-25. https://doi.org/10.1525/nr.2004.7.3.7

Winslade, J. L. (2000). Techno-Kabbalah: The performative language of magick and the production of occult knowledge. TDR: The Drama Review, 44(2), 84-100. https://doi.org/10.1162/1054204 0051058717

Wohleber, C. (1995, December). The man who can scare Stephen King, American Heritage, 46(8). https://www.americanheritage.com/man-whocan-scare-stephen-king?page $=$ show

Young, P. (2002). L.A. exposed: Strange myths and curious legends in the City of Angels. New York: St. Martin's Press.

Zeller, B., E. (2019, 30 December). Altar Call of Cthulhu: Religion and millennialism in H.P. Lovecraft's Cthulhu mythos. Religions, 11(1), 18, 1-17. https://doi.org/10.3390/rel11010018 